\title{
Rethinking the Specific-General Intent Doctrine in California Criminal Law
}

\author{
Douglas R. Young $\dagger$
}

In this Comment the author analyzes the inadequacy of the specificgeneral intent dichotomy in California criminal law and traces the recognition of the doctrine's shortcomings by the California Supreme Court. Although the court has so far failed to replace the doctrine with another approach, the author suggests means by which the doctrine may be modified or replaced by a more flexible model.

I

\section{INTRODUCTION}

\section{A. The Problem}

Because the concepts of specific-general intent and diminished capacity stem from separate origins and do not reflect a unitary thread of logic or policy, their intersection in recent years has created confusion, anomaly and unjust results. In California the specific-general intent dichotony is paradoxically susceptible to both arbitrary and rigid application. Furthermore, it often serves to exclude psychiatric evidence of diminished mental capacity in cases where such evidence niight be especially relevant.

The overlap of diminished capacity and specific-general intent has highlighted the fundamental primciple of criminal law requiring unity of wrongful act and intent. ${ }^{1}$ This conımon law concept is entbodied in California Penal Code section 20, which states that for every crime "there inust exist a union or joint operation of act and intent . . ."2

$\dagger$ B.A. 1971, Yale University; third-year student, Boalt Hall School of Law; Executive Editor, California Law Review.

1. Cal. Pen. CODE $\$ \$ 20,21$ (West 1970). The criminal law requires not only an act but also a guilty mind. This is embodied in the I.atin maxim actus non facit reum nisi mens sit rea (an act does not make one guilty unless his mind is guilty). But not all crimes require that the actor have a particular intention or result in mind. Nor is it always necessary that an individual have knowledge of the circumstances surrounding his act or omission. Some crimes may be committed negligently or carelessly. See, e.g., W. LA. FAVE \& A.W. Scotr, JR., CRIMINAL LAW 191-203 (1972) Thereinafter citcd as LA FAVE \& ScoTT]. For these latter crimes, the requirement of intent is really a fiction. An "immediate" intent is merely the voluntary doing of an act; it does not connote any deeper purposiveness.

2. Cal. Pen. Code $\S 20$ (West 1970).

The commissioners' annotation to section 20 of the California Penal Code 
Thus, the mental state of the defendant is by law as crucial to the issue of guilt or innocence as is the question of the commission of the unlawful act. ${ }^{3}$

The question of mental state is also indispensable in determining whether the defendant is morally culpable for the act. While lack of moral culpability does not always result in the defendant's legal exoneration, ${ }^{4}$ it bespeaks the traditional importance placed upon the question of mental state at the time of the crime. Even under the implied malice concept embodied in the felony-murder rule-which holds that an individual commits murder if he takes the life of another while performing an act with the intent to commit certain felomies ${ }^{5}$ - the California Supreme Court has shown considerable concern for preserving the issue of malice in fact whenever the application of the rule unfairly threatened to obscure it. ${ }^{\circ}$

Such laudable concern, however, has developed unevenly. For example, the concept of criminal intent, an essential element of any crime, is statutorily defined as "manifested by the circunstances connected with the offence, and the sound mind and discretion of the accused." Although the concept of "sound mind" has received judicial attention, the question of the defendent's "discretion" has never been fully developed. ${ }^{8}$ Even the specific-general intent doctrine, which em-

of 1872 quoted with approval the following statement from 1 Bishop's Criminal Law, section 227: " "There is only one criterion by which the guilt of men is to be tested. It is whether the mind is criminal. . . . It is, therefore, a principle of our legal system ... that the essence of the offense is the wrongful intent, without which it cannot exist." [sic].

People v. Wilson, 66 Cal. 2d 749, 760 n.5, 427 P.2d 820, 828 n.5, 59 Cal. Rptr. 156, 164 n.5 (1967).

3. One early writer expressed the importance of the mental state as follows:

The full definition of every crime contains expressly or by inphication a proposition as to a state of mind. Therefore, if the mental element of any conduct alleged to be a crime is proved to have been absent in any given case, the crime so defined is not committed; or, again, if a crime is fully defined, nothing amounts to that crime which does not satisfy that definition.

Stephen, J., in Regina v. Tolson. 23 Q.B.D. 168, 187 (1889).

4. Strict liability crimes are examples of crimes for which the societal interest in protection is weighted more heavily than the question of the defendant's mental capacity or moral culpability. LA FAVE \& SCOTT 218.

5. People v. Rupp, 41 Cal. 2d 371, 260 P.2d 1 (1953); People v. Doyell, 48 Cal. 85,94 (1874).

6. See, e.g., People v. Burton, 6 Cal. 3d 375, 491 P.2d 793, 99 Cal. Rptr. 1 (1971); People v. Wilson, 1 Cal. 3d 431, 462 P.2d 22, 82 Cal. Rptr. 494 (1969); People v. Ireland, 70 Cal. 2d 522, 450 P.2d 580, 75 Cal. Rptr. 188 (1969).

7. Cal. Pen. Code $\$ 21$ (West 1970).

8. In People v. Baker, 42 Cal. 2d 550, 268 P.2d 705 (1954), the California Supreme Court explained that "soundness of mind," as distinguished from "legal sanity," means " "free from flaw, defect or decay, perfect of the kind; undamaged or unimpaired; healthy, not diseased or injured, robust-said of body or mind." Id. at 568, 268 P.2d at 716 (quoting Webster's New International Dictionary 2403). Section 21 was enacted in 1872. However, neither the annotated 1872 Penal Code nor the current Penal Code 
phasizes the intent of the defendant in certain circumstances, fails to support the concept of unity of act and intent in every instance.

After discussing the historical background and significance of the distinction between specific and general intent, this Comment examines the specific-general intent dichotomy and its shortcomings as inanifested in two categories of offenses: assault and homicide. In examining the California Supreme Court's treatment of specific and general intent in these areas, the interaction of the specific-general intent dichotomy with various defenses is analyzed and the proper role of psychiatric testimony is discussed. Finally, alternative methods of alleviating the specificgeneral intent dichotomy are compared.

\section{B. Historical Background}

Although criminal intent was not an element of criminality prior to the twelfth century, ${ }^{10}$ blameworthiness or inoral guilt was required, emphasizing that one's ability to distinguish good from evil should properly underlie any conception of legal responsibility for wrongful actions. ${ }^{11}$ Following the 1843 trial of Daniel M'Naughton, the ability of the defendant to distinguish right from wrong was established as the appropriate test of criminal culpability. ${ }^{12}$ This test was adopted in California in $1864^{13}$ and by the United States Supreme Court in 1897.14 The test, which was solely concerned with the question of legal insanity, did not focus upon the question of intent; rather, it was concerned only with the defendant's overall capacity to comprehend the morality of the act committed.

Meanwhile, the distinction between specific and general intent was evolving to deal with a lesser incapacity: the intoxication of the offender. Regina v. Monkhouse, ${ }^{15}$ the first case to use the words "specific

contain analysis of the word "discretion." Furthermore, the meaning of "discretion" has apparently never been the focal point of judicial inquiry in California.

9. For a more detailed description of the historical background of specific and general intent and mens rea generally, see J. BIGGs, THE GUILTY MIND (1955); Diamond \& Platt, The Origins of the "Right and Wrong" Test of Criminal Responsibility and lts Subsequent Development in the United States: An Historical Survey, 54 CaLIF. L. REv. 1227 (1966); Sayre, Mens Rea, 45 HARv. L. Rev. 974 (1932).

10. Sayre, Mens Rea, 45 HARv. L. REv. 974, 981 (1932).

11. Id. at 1006 .

12. M'Naghten's Case, 8 Eng. Rep. 718 (Flouse of Lords, 1843). The exact spelling of Daniel M'Naughton's name has been the source of speculation. See, Diamond, On the Spelling of Daniel M'Naghten's Name, 25 OHo ST. L.J. 84 (1964). The English Reports spell it "M'Naghten." However, in keeping with the spelling apparently preferred by the California Supreme Court, this Comment will spell the name "M'Naughton."

13. People v. Coffman, 24 Cal. 230 (1864).

14. Davis v. United States, 165 U.S. 373 (1897).

15. 4 Cox Crim. Cas. 55 (1849). In emphasizing that evidence of the actor's conduct, including intoxication, was to be considered in determining whether the 
intention," focused on the question whether the effect of intoxication could be considered as evidence regarding the intent to murder. It is not certain that the judge in Monkhouse meant to direct attention to a special mental element for particular crimes. However, because mens rea is required for all but strict liability crimes, to have allowed intoxication to negate each possible intent would have undermined the law ${ }^{\mathbf{1 6}}$ by providing a defense to too many crimes. So, as an apparent compromise, the distinction between specific and general intent was drawn in order that evidence of intoxication would be allowed to negate intent only where intent was an element to be affirmatively proven. ${ }^{17}$

\section{Definitions}

Perhaps the most difficult aspect of any discussion of mens rea is the danger that terms may be confused. Accordingly, before analyzing the current state of the law some definitions should be introduced.

In California, the basic concept of "intent" has been described in terms of the immediate purpose to do the prohibited act, without regard to motive..$^{18}$ Normally, where an individual capable of entertaining a criminal intent ${ }^{19}$ commits a prohibited act without justification, the law

defendant intended to kill, Coleridge, J., used the phrase "specific intention." Id. at 56. He also stated: "To ascertain whether or not [the lack of power to form any specific intention] did exist in this instance, you must take into consideration the quantity of spirit he had taken, as well as his previous conduct." Id.

16. Hall, Intoxication and Criminal Responsibility, 57 HARV. L. REV. 1045, 1049 (1944).

17. I J. Bishop, Bishop on Criminal Law 299 (9th ed. 1923).

18. People v. McClennegan, 195 Cal. 445, 234 P. 91 (1925); CaL. Pen. Code $\S 7$ (West 1970).

The precise meaning of "intent" has been the source of considerable comment throughont the history of the law. According to one definition, "intent" is reflected in the actor's wish or desire: "When the doer of an act adverts to a consequence of the act and desires it to follow, he is said to intend that conseqnence." W. MARKBY, ELEMENTS OF LAW $\$ 217$ (6th ed. 1905). A contrary definition notes that one can intend an act without desiring it, as when it appears likely that a third person's death will be caused as a consequence of the killing of someone else. J. Austin, JuRISPRUDENCE, 434-37 (3d ed. 1869). Still a third definition understands "intent" to apply when: (1) the individual wishes the result of the act and commits the act for this pnrpose; and (2) when, at the time he acts, the individual adverts to the consequences in question as ones which will necessarily result from the act, even thongh he would not desire these secondary consequences if he could avoid them while still bringing about the consequence which he primarily desired. J. SALMOND, JURISPRUDENCE 413-17 (1st ed. 1902).

19. Penal Code section 26 states:

All persons are capable of committing crimes except those belonging to the following classes:

One-Children under the age of fourteen, in the absence of clear proof that at the time of committing the act charged against them, they knew its wrongfulness.

Two-Idiots.

Three-Lunatics and insane persons.

Four-Persons who committed the act or made the omission charged under 
imputes a criminal intent, even though such intent was not defined as an element of the offense. ${ }^{20}$ Such imputed intent is an example of the California concept of general intent, which is employed to categorize those crimes in which no particular mental element must be demonstrated. $^{21}$ In general intent crimes, the intentional domg of the prohibited act constitutes the offense regardless of good motive or ignorance of the criminal character of the act. ${ }^{22}$ An act committed negligently, therefore, may be a general intent crime.

By contrast, specific intent crimes require something more. A particular mental state is one of the requisite elements of a specific intent crime, and the charge of the crime will be imsufficient unless it contains an allegation of that mental state. ${ }^{23}$ Most importantly, specific intent crimes may be exculpated or reduced by a defense of diminished capacity; general intent crimes may not. ${ }^{24}$ Examples of specific intent crimes include: burglary, which requires an intent to commit a felony or larceny; ${ }^{25}$ attempt crimes, which require both the specific intent to do the unlawful act and a direct, unequivocal act toward that end; $;^{20}$ larceny, which involves the taking of another person's property with the

an ignorance or mistake of fact, which disproves any criminal intent.

Five-Persons who committed the act charged without being conscious thereof.

Six-Persons who committed the act or made the omission charged through misfortune or by accident, when it appears that there was no evil design, intention, or culpable negligence.

Seven-Married women (except for felonies) acting under the threats, command, or coercion of their husbands.

Eighth-Persons (unless the crime be punishable with death) who committed the act or made the omission charged under threats or menaces sufficient to show that they had reasonable cause to and did believe their lives would be endangered if they refused.

Cat. Pen. Code $\$ 26$ (West 1970). The accused's sound mind and discretion are also relevant to intent. CAL. PEN. CoDe $\$ 21$ (West 1970).

20. In re Ahart, 172 Cal. 762, 159 P. 160 (1916); People v. Peak, 66 Cal. App. 2d 894, 153 P.2d 464 (1944).

21. "General intent" has never been given a textbook definition in California.

22. People v. Gory, 28 Cal. 2d 450, 170 P.2d 433 (1946); People v. O'Brien, 96 Cal. 171, 31 P. 45 (1892).

23. People v. Mooney, 127 Cal. 339, 59 P. 761 (1899). "Specific" intent should not be confused with "motive," which is descriptive of the reasons for an act. One may do good things for bad reasons, and bad things for good reasons; but, with few exceptions, the law looks only to the act or result achieved and to the purposeful intention behind the act.

24. People v. Noah, 5 Cal. 3d 469, 487 P.2d 1009, 96 Cal. Rptr. 441 (1971).

25. Cal. Pen. Code $\$ 459$ (West 1970); People v. Smith, 63 Cal. 2d 779, 409 P.2d 222, 48 Cal. Rptr. 382 (1966), cert. denied, 388 U.S. 913, rehearing denied, 389 U.S. 893 (1967).

26. Cal. Pen. Code $\$ \$ 663,664$ (West 1970); People v. Miller, 2 Cal. 2d 547, 42 P.2d 308 (1935); People v. MacEwing, 216 Cal. App. 2d 33, 30 Cal. Rptr. 476 (2d Dist. 1963). Assault, which is an attempted battery, is for policy reasons made an exception to this rulle. See text accompanying notęs 38-49 infra, 
specific intent, at the time of the taking, to permanently appropriate the property, ${ }^{27}$ and conspiracy, which requires that the accused possess an intent to violate the law in concert with others, either by committing an unlawful act or by committing a lawful act by unlawful ineans. ${ }^{28}$ Furthermore, the so-called "intent" crimes-such as assault with intent to inurder, ${ }^{29}$ or assault with intent to rape, ${ }^{30}$ or administering poison with intent to kill ${ }^{31}$ _obviously require proof of a specific intent. Evidence of specific intent may be deduced froin events surrounding the act or omission, and circumstantial evidence may be used. ${ }^{32}$ In no case, however, may the specific intent be presumed solely from the conscious commission of the unlawful act; rather, it must be proven beyond a reasonable doubt. . $^{33}$

\section{II}

\section{ASSAULT}

Cases involving crimes of assault, particularly those involving intoxicated offenders, forcefully illustrate some of the problems created by reliance upon the specific-general intent dichotomy. In applying the law of criminal intent to the intoxicated perpetrator of assault, competing policy considerations must be adjusted and balanced. First, the tension must be resolved between society's right to protection and the defendant's interest in having both act and intent proven against him beyond a reasonable doubt. The balancing of these interests necessitates some degree of flexibility in the application of the law, which raises a second spectrum of competing interests. Too little flexibility may result in miscarriages of justice, while too much may yield arbitrary and purely result-oriented decisions. In short, justice should be blind-but not without vision.

The specific-general intent formula is too clumsy a tool to enable courts to draw the fine lines necessary to resolve these complex problems. In some respects this bifurcated system, like its constitutional law cousin the "two-tiered equal protection test," 34 is too rigid; defendants (1894).

27. Cac. Pen. CoDe. $\$ 484$ (West 1970); People v. Brown, 105 Cal. 66, 38 P. 518

28. Car. Pen. Code $\$ 182$ (West 1970); People v. Marsh, 58 Cal. 2d 732, 376 P.2d 300, 26 Cal. Rptr. 300 (1962).

29. Cal. Pen. CoDe $\$ 217$ (West 1970).

30. Cal. Pen. Code $\$ 220$ (West 1970).

31. Cal. Pen. Code $\$ 216$ (West 1970).

32. Cal. Pen. CODE $\$ 21$ (West 1970).

33. People v. Fleming, 94 Cal. 308, 29 P. 647 (1892).

34. In determining whether a statute violates equal protection, the United States Supreme Court has traditionally employed a highly rigidified "two-tier" standard of review. If the statute disadvantages a "suspect class" or infringes upon a "fundamental 
charged with a specific intent crime may avail themselves of several potential mental state defenses, while those charged with general intent crimes are permitted virtually none. ${ }^{35}$ Conversely, the specific-general intent dichotomy is sonnetimes too flexible. Because the terms themselves lack precise meaning, courts are often free to label a crime specific or general intent depending upon the desired result.

All of these policy considerations were present when the California Supreme Court, in two important decisions, grappled with the problem of the relationship between assault and intoxication. In the first case, ${ }^{3 v}$ the court recognized the limited usefulness of the specific-general intent dichotomy, acknowledged the presence of other important factors, and expressly fashioned its decision in such terms. In the subsequent case, ${ }^{37}$ however, the court retreated from this laudable path and again sought shelter in the specific-general intent maze.

\section{A. People v. Hood: By-passing Specific-General Intent}

In People v. Hood ${ }^{38}$ the Califorma Supreme Court frankly acknowledged the limited usefulness of reliance upon the specific-general intent dichotomy, at least in dealing with the crime of assault with a deadly weapon. The defendant had been convicted of assault with a deadly weapon upon a police officer and assault with intent to commit

interest" it is presumed invalid, is subject to "strict judicial scrutiny," and must serve a "compelling state interest." All other statutes carry a presumption of validity and will be upheld unless no conceivable "rational basis" can be found for their existence. See generally Developments in the Law-Equal Protection, 82 HARv. L. REv. 1065 (1969). Under this traditional test the presumptions of validity or invalidity are so strong that the constitutionality of virtually any statute can be predicted solely on the basis of which standard of review was applied by the Court.

The inflexibility of this approach, and the anomalies it may produce, lias led the Court in recent years to blur the distinction between the two standards of review. See generally Gunther, The Supreme Court, 1971 Term-Foreword: In Search of Evolving Doctrine on a Changing Court: A Model for a Newer Equal Protection, 86 HaRv. L. REv. 1 (1972). Furthermore, individual members of the Court have expressed dissatisfaction with the inflexibility of the two-tier approach:

To begin, I must once more voice my disagreement with the Court's rigidified approach to equal protection analysis. ... The Court apparently seeks to establish today that equal protection cases fall into one of two neat categories which dictate the appropriate standard of review-strict scrutiny or mere rationality. But this Court's decisions in the field of equal protection defy such easy categorization.

San Antonio School Dist. v. Rodriguez, 411 U.S. 1, 98 (1973) (Marslıall, J., dissenting). See also Gunther, supra, at 17-20. The analogy between the inflexibility of the specificgeneral intent dichotoiny and the traditional equal protection test has been drawn because the latter lias received far more critical analysis - from both the Court and commentators.

35. See note 24 supra and accompanying text.

36. People v. Hood, 1 Cal. 3d 444, 462 P.2d 370, 82 Cal. Rptr. 618 (1969).

37. People v. Rocira, 3 Cal. 3d 893, 479 P.2d 372, 92 Cal. Rptr. 172 (1971).

38. 1 Cal. 3d 444, 462 P.2d 370, 82 Cal. Rptr. 618 (1969). 
murder. The supreme court reversed on several grounds, imcluding the trial court's conflicting instructions on the effect of voluntary intoxication, ${ }^{39}$ which contained an instruction applicable only to general intent crimes and thus inappropriate to a charge of assault with intent to commit murder. ${ }^{40}$ Holdimg that the erroneous instructions were sufficiently prejudicial to require reversal, the court also discussed the legal effect of intoxication in cases of assault with a deadly weapon in order to guide the lower court on retrial. ${ }^{41}$

In considering whether intoxication is a defense to the crime of assault or assault with a deadly weapon, the court focused on the need to reconcile two competing theories of justness in the treatment of intoxicated criminal offenders. The court explicitly recognized that although the moral culpability of the drunken offender might be less than that of one who is sober, society is reluctant to allow one who commits a crime while voluntarily intoxicated to thereby escape the consequences of his deed. ${ }^{42}$ According to the court, the confusion regarding the requisite intent for such crimes of assault arises frown the fact that although the relevant sections of the Penal Code ${ }^{43}$ do not isolate the particular mental elements involved, the word "attempt" in Penal Code section 240 "strongly suggests goal-directed, intentional behavior. This uncertainty accounts for the conflict over whether assault is a crime only of intention or also of recklessness." 44 Furthermore, the court acknowl-

39. Throughout this Comment "intoxication" and "voluntary intoxication" will be used interchangeably. Whenever involuntary intoxication is specifically relevant to the discussion it will be so designated.

40. $1 \mathrm{Cal}$. 3d at $452,462 \mathrm{P} .2 \mathrm{~d}$ at $374,82 \mathrm{Cal}$. Rptr. at 622.

41. Id. Other grounds for reversal included the following: (1) the trial court had erred prejudicially in failing to instruct on the lesser included offense of assault with a deadly weapon; and (2) the trial court had erred by failing to instruct that if the officer had exceeded his duties by using excessive force, or if the defendant reasonably so believed, no conviction could be obtained for assault with a deadly weapon upon a police officer withiu the ineaning of section 245 of the Penal Code.

42. 1 Cal. 3d at 455,462 P.2d at 377, 82 Cal. Rptr. at 625.

43. Id. at 457, 462 P.2d at 378, 82 Cal. Rptr. at 626. Penal Code section 22 declares that voluntary intoxication is not a defense to crime, and continues in part:

Whenever the actual existence of any particular purpose, inotive, or intent is a necessary eleinent to constitute any particular species or degree of crime, the jury must take into consideration the fact that the accused was intoxicated at the time in determining the purpose, motive, or intent with which he committed the act.

CAL. PEN. CODE $\$ 22$ (West 1970). This has been interpreted to include intoxication by drugs as well as hquor. See, e.g., People v. Baker, 42 Cal. 2d 550, 572, 268 P.2d 705, 718-19 (1954). However, the fact that one takes a drug knowing it to be intoxicating is not conclusive proof that the act was voluntary, if the taking was compelled by medical necessity. See id. at 575, 268 P.2d at 720-21.

44. 1 Cal. 3d at 457, 462 P.2d at 378, 82 Cal. Rptr. at 626 (footnote omitted). The Penal Code defines "assault" as follows: "An assault is an unlawful attempt, coupled with a present ability, to commit a violent injury on the person of another." CaL. PEN. CODE $\S 240$ (West 1970). 
edged that specific and general intent have been notoriously difficult to define ${ }^{45}$ and that the difference between them is often only linguistic:

It is true that in most cases specific intent has come to mean an intention to do a future act or achieve a particular result, and that assault is appropriately characterized as a specific intent crime under this definition. An assault, however, is equally well characterized as a general intent crime under the defimition of general intent as an intent merely to do a violent act. Therefore, whatever reality the distinction between specific and general intent may have in other contexts, the difference is chimerical in the case of assault with a deadly weapon or simple assault. Since the definitions of both speeific intent and general intent cover the requisite intent to commit a battery, the decision whether or not to give effect to evidence of intoxication must rest on other considerations. ${ }^{46}$

Turning to such "other considerations," the court was primarily influenced by alcohol's tendency to "distort judgment and relax the controls on aggressive and anti-social impulses." 77 The court asserted that alcohol does not have a serious effect upon the ability to engage in simple, goal-directed behavior, such as the ability to form the intent to strike another. Alcohol's effect, rather, is to encourage rash and impulsive acts and to increase susceptibility to passion and anger. The court therefore concluded that it would be "anomalous" to allow evidence of intoxication to relieve a person of responsibility for crimes such as assault with a deadly weapon or simple assault, "which are so frequently committed in just such a manner." 48 However, the court was careful to distinguish from this holding those crimes that have traditionally been characterized as crimes of specific intent. Thus, although evidence of intoxication would be disregarded in cases of assault with a deadly weapon, it would still be considered in cases such as assault with intent to murder. ${ }^{49}$

\section{B. People v. Rocha: Reviving Specific-General Intent}

Hood had unequivocally stated that the nature of the requisite intent for assault with a deadly weapon or simple assault is such that it is not "susceptible to negation through a showing of voluntary intoxication." ${ }^{50}$ Nonetheless, the confusion surrounding the question had not been abated. Despite the supreme court's attempt to by-pass the specific-

45. 1 Cal. 3d at 446,462 P.2d at 377, 82 Cal. Rptr. at 625 .

46. Id. at 457-58, 462 P.2d at 378, 82 Cal. Rptr. at 626 (emphasis added).

47. Id. at 458, 462 P.2d at 378-79, 82 Cal. Rptr. at 626-27.

48. Id. at 458, 462 P.2d at 379, 82 Cal. Rptr. at 627 .

49. Id. at 458-59, 462 P.2d at 379, 82 Cal. Rptr. at 627.

50. Id. at 458, 462 P.2d at 379, 82 Cal. Rptr. at 627 (quoting Parker v. United States, 359 F.2d 1009, 1012-13 (D.C. Cir. 1966)). 
general intent dichotomy, lower courts continued to rely upon such formulations in instructing upon the effects of intoxication in assault cases. ${ }^{51}$ Two years later therefore, in People $v$. Roch $a{ }^{52}$ the court again considered both whether assault with a deadly weapon was a specific intent crime and whether a defense of intoxication would be recognized. The resulting opinion was true to the letter, though not the spirit, of Hood.

The court acknowledged that the Hood decision had rested on public policy grounds rather than on the basis of the specific-general intent doctrine.$^{53}$ However, it went on to state that a second rationale for the Hood decision had been recognition of the difference between the intent to commit a battery, which has always been deemed a general intent, and the intent to commit an assault for the purpose of causing a particular additional result, such as murder or rape, which has been deemed a specific intent. ${ }^{54}$ Therefore, it analyzed the legislative and case history behind Penal Code section 245, particularly noting that when the section was revised in 1873 the phrase "with intent to do bodily harm" was deleted. ${ }^{.5}$ Although the court reaffirmed the holding of People v. Carmen ${ }^{56}$ that mere reckless conduct alone does not constitute assault, it refused to classify assault as a specific intent crime.

Instead, relying upon the fact that "traditionally" sinuple assault and assault with a deadly weapon have been "referred to" as general intent crimes, the court "adhered" to that tradition:

51. For example, one treatise and several cases interpreted the decision as meaning that neither assault nor assault with a deadly weapon should be regarded as specific inteut crimes. See, e.g., B. WITKIn, CALIForNIA CRIMEs (1969 Supp.) § 264 at 88-89; People v. Livingston, 4 Cal. App. 3d 251, 84 Cal. Rptr. 237 (1st Dist. 1970). Another authority, however, reached an opposite result:

An assault with a deadly weapou is an unlawful attempt, coupled with a present ability, with the specific inteut to commit a violent injury upon the person of another with a deadly weapon. . . .

The necessary elements of the offense are the unlawful attempt with the specific intent to commit a violent injury upon the person of another by the use of a deadly weapon iu that atteinpt, and the then present ability to accomplish the injury.

Committee on Standard Jury Instructions, Criminal, of the Superior Court of Los Angeles County, California, Caltfornia Jury Instructions, Criminat $\$ 9.03$ (3d rev. ed. 1970) [hereinafter cited as CAIJIC]. In addition, CAIJIC section 9.00 defines assault as "an unlawful attempt, coupled with a present ability and with the specific intent to commit a wrongful act by means of physical force upon the person of another." See also People v. Marceaux, 3 Cal. App. 3d 613, 83 Cal. Rptr. 798 (3d Dist. 1970); People v. Spence, 3 Cal. App. 3d 599, 83 Cal. Rptr. 711 (2d Dist. 1970).

52. 3 Cal. 3d 893, 479 P.2d 372, 92 Cal. Rptr. 172 (1971).

53. Id. at 897-98, 479 P.2d at 375, $92 \mathrm{Cal}$. Rptr. at 175 .

54. Id. at 898,479 P.2d at $375,92 \mathrm{Cal}$. Rptr. at 175 .

55. Id. at $898,479 \mathrm{P} .2 \mathrm{~d}$ at $375-76,92 \mathrm{Cal}$. Rptr. at 175-76.

56. 36 Cal. 2d 768, 228 P.2d 281 (1951).

57. 3 Cal. $3 \mathrm{~d}$ at $898-99,479$ P.2d at 376,92 Cal. Rptr. at 176. 
An assault is ... an attempt to commit a battery. ... A Accordingly, the intent for an assault with a deadly weapon is the intent to attempt to commit a battery, a battery being "any willful and unlawful use of force or violence upon the person of another." (Pen. Code \$242) We conclude that the criminal intent which is required for assault with a deadly weapon ... . is the general intent to wilfully commit an act the direct, natural and probable consequences of which if successfully completed would be the injury to another. Given that intent it is immaterial whether or not the defendant intended to violate the law or knew that his conduct was unlawful. The intent to cause any particular injury ...., to severely injure another, or to injure in the sense of inflicting bodily harin is not necessary. ${ }^{58}$

Given the fact that the recklessness exception created in Carmen was reaffirmed, it is apparent that the result of Rocha was the recognition of a new category of general intent: effectively a general-specific intent hybrid.

\section{Understanding Hood and Rocha: "Chimera" As a Foundation for Law}

The creation of the Rocha hybrid added a new layer of confusion to an area already overburdened in that regard. More disturbing, however, was the Rocha court's renege on the promise first held out in Hood. Rocha constitutes a return to the practice of reaching otherwise desirable results by mamipulating legal definitions rather than by frankly acknowledging the policy considerations properly underlying such results. Hood had instructed that in the assault context the difference between specific and general intent is "chimerical," 59 yet, the Rocha decision rested precisely on that chimerical difference. The Rocha court stressed the deletion of the word "intent" from the relevant statute, forgettimg Hood"s warning that "[t]oo often the characterization of a particular crime as one of specific or general intent is determined solely by the presence or absence of words [such as intent]." "In short, the Hood opinion revealed the various ways in which the vagueness of the specific-general intent doctrine might be arbitrarily manipulated; Rocha proved the point.

58. Id. at 899,479 P.2d at $376-77,92$ Cal. Rptr. at 176-77.

59. 1 Cal. $3 d$ at 458,462 P.2d at 378, 82 Cal. Rptr. at 626.

60. Id. at 456, 462 P.2d at 377-78, 82 Cal. Rptr. at 625-26. Moreover, the statutory construction relied upon in Rocha concerned a legislative change which had been made in 1873. However, in discussing a related statute, the court in Hood had pointed out that in 1872 " 'specific' and 'general' intent were not yet terms of art." Id. at 457,462 P.2d at 378, 82 Cal. Rptr. at 626 . The significance of Rocha's reliance upon possibly misleading statutory language is magnified by the fact that the court otherwise engaged in such sparse analysis of the reasons for treating assault as a general intent crime. 
The most dismaying aspect of Rocha is that the court paid such a high price to achieve so little. Characterizing assault as a general intent crime will indeed negate a defense of voluntary intoxication. Such a result, however, had already been mandated in Hood for reasons for more compelling than those advanced in Rocha. Yet, as a result of Rocha, courts in the future may be haunted by the classification of assault as a crime of general intent; defenses to assault-especially mental illness-which from a public policy viewpoint ought to be recognized, may be precluded by the Rocha definition of intent. Courts will then face the dilemma of either reaching unjust results or being forced to engage in further adulteration of the definition of general intent.

Fimally, account must be taken of the price paid by Rocha in terms of judicial credibility. The court's prestige is not enhanced by first announcing that a distinction is chimerical and, two years later, resting a decision on that very distinction. If the criminal law requires unity of an act and an intent, the fundamental issue of intent must be treated as a real and meaningful concept worthy of consistent development.

\section{III}

\section{HOMTCIDE}

\section{A. General Principles}

\section{Moral Turpitude}

Unlike other crimes, lomicide involves special inental states far more complex than those identified with general or specific intent as the terms are normally employed. For example, in most specific intent crimes the inquiry into mental state is limited to the question whether the defendant had the purpose to achieve the proscribed result. Homicide, by contrast, entails inquiry into a far wider spectrum of mental considerations, mcluding motivation, volition, cognition, and the ability meaningfully to reflect upon the consequences of the act. First degree murder requires both premeditation and inalice aforethought; ${ }^{61}$ if malice aforethought but no premeditation is proven, the lomicide is second degree murder. ${ }^{62}$ Distinguished from murder is the crime of manslaughter, which is homicide with neither malice aforethought nor premeditation. ${ }^{63}$

The existence of these additional mental states and the complicated and sometimes confusing ineanings which have been assigned to them reflect the fact that of all crimes homicide involves one of the highest

61. Cal. Pen. Code $\S \S 187,189$ (West 1970).

62. Cal. Pen. Code $\S 189$ (West 1970).

63. Cal. Pen. Code $\$ 192$ (West 1970). 
levels of moral culpability. The different categories and degrees of homicide are intended to distinguish varying levels of moral turpitude ${ }^{\mathbf{u}}$ and to formalize social antipathy accordingly. Because the tensions between society's interests and those of the defendant are nowhere more strained than in the case of homicide, the fine lines between the requisite mental elements for various homicides are necessary to accommodate the competing interests involved. Unfortunately, where the courts have viewed the societal interest in protection ${ }^{85}$ from such crimes as outweighing the defendant's imterest in the thorough consideration of his mental state at the time of the crime, the issue of the requisite mental element of the homicide often has been manipulated or distorted.

\section{The Insanity Defense and Diminished Capacity}

The peculiarities of the insanity defense in California underscore the need to distinguish between the various mental states required for homicides. Since insanity is a complete defense concerned with the defendant's overall understanding and responsibility for the crime charged, the individual inental elements required for a particular crime are not relevant to the insanity inquiry. ${ }^{60}$ The so-called "M"Naughton

64. The California Supreme Court has expressed this notion as follows:

"Dividing intentional homicides into murder and voluntary manslaughter was a recognition of the infirmity of human nature. Again dividing the offense of murder into two degrees is a further recognition of that infirmity and of difference in the quantum of personal turpitude of the offenders. . .."

People v. Wolff, 61 Cal. 2d 795, 820, 394 P.2d 959, 974, 40 Cal. Rptr. 271, 286 (1964) (quoting People v. Holt, 25 Cal. 2d 59, 89, 153 P.2d 21, 37 (1944)) (emphasis added by court in Wolff).

65. Of course, protection or deterrence is not the only societal interest involved in every case. Often other interests, such as retrihution or rehabilitation of the offender, are paramount.

66. California provides for a bifurcated trial when the defendant pleads both not guilty and not guilty by reason of insanity. CAL. PEN. CODE $\$ 1026$ (West 1970). The proceedings are considered to be one trial, in the course of which the issue of the defendant's sanity or insanity is examined separately from the question of his commission of the act charged. People v. Rupp, 41 Cal. 2d 371, 260 P.2d 1 (1953); People v. Wells, 33 Cal. 2d 330, 202 P.2d 53, cert. denied, 338 U.S. 836 (1949); People v. Cordova, 14 Cal. 2d 308, 94 P.2d 40 (1939); People v. French, 12 Cal. 2d 720, 87 P.2d 1014 (1939); People v. Marshall, 209 Cal. 540, 289 P. 629 (1930); People v. Leong Fook, 206 Cal. 64, 273 P. 779 (1928); People v. Troche, 206 Cal. 35, 273 P. 767 (1928), appeal dismissed, 280 U.S. 524 (1929). A verdict of guilty at the first phase of the bifurcated trial stands only on the condition that the defendant is found to have been sane at the time of the offense. If the second phase of the trial yields a decision that the defendant was insane at the time of the commission of the offense, and if he does not appear to the court to have recovered sanity, the court must direct that he be confined in the state hospital for the criminally insane. CAL. PEN. Code $\S 1026$ (West 1970). Even if it appears to the court that the defendant has recovered sanity at the time of the trial, he must be remanded to the custody of the sheriff until the issue of his sanity has been finally determined "in the manner prescribed by the law." Cax. PeN. Code $\$ 1026$ (West 1970). In addition, there are specific statutory provisions for dealing with the situation 
test" requires that the accused's mental faculties must be so diseased or deranged as to render him incapable of distinguishing right from wrong or comprehending the nature and quality of the act for which he is charged. ${ }^{67}$

The rigidity of the insanity defense magnifies the significance of diminished capacity as it relates to the specific mental states required for homicide. The law holds that although intoxication or mental defect or disease are not exculpatory, they may at least negate the specific intent elements of murder, thereby reducing it to manslaugter ${ }^{68}$ Diminished capacity therefore offers the defendant the only middle ground between life imprisonment, or possibly death (if he is convicted) and a potentially indefinite commitment to an insane asylum (if he is found not guilty by reason of insanity). Because expanding notions of diminished capacity have been used to mitigate the harshness of the MNaughton rule, the impetus to revise the strict insanity test has been defused. For example, in a concurring opinion in People v. Nash, ${ }^{69}$ Justice Peters wrote:

In the past I have felt some dissatisfaction with the rigid application of the M'Naughton rule. Shortly after the adoption in 1927 of the provisions of the Penal Code providing for a bifurcated trial where an accused pleads not guilty and not guilty by reason of insanity, this court decided a series of cases rigidly restricting the admissibility of evidence of mental condition on the trial of the guilt issue.... As I understand the recent decisions of this court, relevant evidence of an accused's mental condition affecting intent where intent is an element of the crime charged is now admissible on the

in which a defendant committed to a hospital for the insane recovers his sanity. CAL. PEN. CODE $\$ \S 1026,1026$ a (West 1970). One provision requires that a hearing on an application for release on the ground that sanity has been restored must not be held until the prisoner has been confined for a period of not less than 90 days; and if he is not found sane at that time he must wait one year before re-filing. CAL. PEN. CODE $\$ 1026 \mathrm{a}$ (West 1970). The argument that this mandatory confinement unjustly inflicts punishment for an act committed while insane has been rejected on the ground that this confinement is not in the legal nature of punishment. In re Slayback, 209 Cal. 480, 288 P. 769 (1930).

67. People v. Daugherty, 40 Ca1. 2d 876, 256 P.2d 911, cert. denied, 346 U.S. 827 (1953); People v. Willard, 150 Cal. 543, 89 P. 124 (1907). The original M'Naughton Test of insanity required proof that, at the time of committing the act, the defendant was "labouring under such a defect of reason, from disease of the mind, as not to know the nature and quality of the act . . . or, if he did know it, that he did not know he was doing what was wrong." M'Naghten's Case, 8 Eng. Rep. 718, 722 (House of Lords, 1843). The California version of the test is more liberal: "First, did the defendant have sufficient mental capacity to know and understand what he was doing, and second, did he know and understand that it was wrong and a violation of the rights of another?" " People v. Wolff, 61 Cal. 2d 795, 801, 394 P.2d 959, 962, 40 Cal. Rptr. 271, 274 (1964). (1949).

68. People v. Wells, 33 Cal. 2d 330, 202 P.2d 53, cert. denied, 338 U.S. 836

69. 52 Cal. 2d 36, 338 P.2d 416 (1959). 
trial of the guilt issue. Thus the basis of my dissatisfaction with the rigid application of the M'Naughton rule no longer exists. ${ }^{70}$

Thus, in considering the broadening concept of malice aforethought, it should be remembered that the court has employed malice aforethought as a tool with which to fashion just results in varying factual circumstances.

\section{B. Malice Aforethought}

\section{General}

Malice aforethought illustrates the range of complexities characteristic of the mental states that define homicides and focuses attention on the policy decisions involved in applying these abstract mental states to specific cases. Malice has a special, albeit unclear, meaning as applied to lomicide. It appears to be centered in a notion of free will, or ability to choose. For this reason, the meaning which has been attached to malice aforethought demands a continuous reevaluation of the relationship between law and psychiatry. To some this relationship is perceived as adversary. ${ }^{71}$ However, recognition of the proper roles of the two disciplines can alleviate this tension and yield results satisfactory to the legal profession and to society.

\section{The Modern Meaning: A Specific Intent Centered in Free Will}

In order to convict a defendant for murder, the prosecution must prove not only that he in fact committed the fatal act, but also that he did so with malice aforethought. The modern meaning of "malice aforethought" must not be confused with the meaning of "malice" as set forth in Penal Code section 7; indeed, the California Supreme Court has stated that the definition of malice contained in Penal Code section 7 "should not be read to the jury in a murder case."72 Ill will or hatred, therefore, are not the touchstones of malice aforethought. This was made clear as early as 1707, in the case of Regina v. Mawgridge:

70. Id. at $54-55,338$ P.2d at 428. Similar language is found in other cases: " '[T]he defense of mental illness not amounting to legal insanity is a "significant issue" in any case in which it is raised by substantial evidence. Its purpose and effect are to ameliorate the law governing criminal responsibility prescribed by the M'Naughton rule ... ." People v. Conley, 64 Cal. 2d 310, 319, 411 P.2d 911, 916, 49 Cal. Rptr. 815, 820 (1966) (quoting People v. Henderson, 60 Cal. 2d 482, 490, 386 P.2d 677, 682, 35 Cal. Rptr. 77, 82 (1963)).

71. See, e.g., Ennis \& Litwack, Psychiatry and the Presumption of Expertise: Flipping Coins in the Courtroom, 62 CALIF. L. Rev. 693 (1974); Hakeem, A Critique of the Psychiatric Approach to Crime and Correction, 23 Law \& ConTEMP. ProB. 650 (1958); Schmideberg, The Promise of Psychiatry: Hopes and Disillusionment, $57 \mathrm{Nw}$. U.L. Rev. 19 (1962); Szasz, Psychiatry, Ethics and the Criminal Law, 58 ColuM. L. REV. 183 (1958).

72. People v. Gorshen, 51 Cal. 2d 716, 730-31, 336 P.2d 492, 501 (1959). 
Some have been led into mistake by not well considering what the Passion of Malice is; they have construed it to be a Rancour of Mind lodged in the Person Killing, for some considerable time before the commission of the Fact, which is a mistake arising from the not well distinguishing between Hatred and Malice. Envy, Hatred and Malice are three distinct Passions of the Mind. . . . Malice is a design formed of doing mischief to another. ${ }^{73}$

This definition of malice as the "design formed" carries the seeds of the modern concept of malice aforethought. In Califormia, for example, malice aforethought is a specific intent, ${ }^{74}$ capable of negation by evidence of diminished capacity. ${ }^{75}$ Malice aforethought is thus characterized by cognitive and volitional ability-in essence by free will in the sense of the uninhibited ability to make a rational clioice to commit a person-endangering act.

The real beginning of this understanding of the concept of malice aforethought can be traced to the landmark case of People v. Wells, ${ }^{76}$ reaffirmed 10 years later in People v. Gorshen, ${ }^{77}$ in which the California Supreme Court recognized that diminished capacity caused by mental disease or disorder may negate an individual's ability to formulate the specific intent required to commit certain crimes. Thus, an unreasonable fear of attack, though insufficient to justify a claim of self-defense, could reduce a charge from murder to manslaughter:

If he acted only under the influence of fear of bodily harn in the belief, honest though unreasonable, that he was defending himself ... then defendant would not have committed the offense charged, for the essential element of "malice aforethought" would be lacking. ${ }^{78}$

73. Holt, J., in Regina v. Mawgridge (1717), reported in J. KELYNG, A REPORT OF Drvers Casts in Pleas of the Crown AdJudged and Determined: IN the ReIGN of the Late King Charles II . . . To Which Is AdDed the Reports of Three Modern CASES . . . 126 (London, printed for Isaac Cleave, 1708).

74. In People v. Wells, 33 Cal. 2d 330, 202 P.2d 53, cert. denied, 338 U.S. 836 (1949), which involved an assanlt by a life prisoner upon a guard, the California Supreme Court stated:

This issue, then, necessarily involves proof of a mental state (the specific intent or motive amounting to malice aforethought) and as pertinent and material to resolving such issue, the prosecntion ... w was properly allowed to introduce evidence of objective manifestation ... f from which it could be inferred that he bore such "malice aforethought . . . ."

Id. at 343,202 P.2d at 61 .

75. Id. at $346-51,202$ P.2d at 63-66. The California jury instructions regarding the diminished capacity to form a specific mental state declare that "a certain specific intent or mental state essential to constitute a crime" may be refuted by evidence of "abnormal mental or physical condition." CALJIC $\$ 3.35$ at 93 .

76. 33 Cal. 2d 330, 202 P.2d 53, cert. denied, 338 U.S. 836 (1949). The defendant had been convicted under Penal Code section 4500 which provides that certain kinds of assaults committed "with malice aforethought" by life-term prisoners are capital offenses.

77. 51 Cal. 2d 716, 336 P.2d 492 (1959).

78. 33 Cal. $2 \mathrm{~d}$ at 345,202 P.2d at $62-63$. 
Wells and Gorshen were followed by a similar emphasis in People $v$. Conley ${ }^{79}$ upon cognitive capacity: "If, because of mental defect, disease, or intoxication . . . the defendant is unable to comprehend his duty to govern his actions in accord with the duty imposed by law, he does not act with malice aforethought and cannot be guilty of murder in the first degree." 80

Besides the impairment of cognitive powers, California has recognized a complementary defense to malice aforethought: dininished capacity arising from lack of volition. In People v. Cantrell, ${ }^{81}$ the supreme court reviewed the first degree murder conviction of a man who, while engaged in a statutory sex offense, panicked at the screams of his young victim and strangled him. The psychiatric testimony was to the effect that the strangulation was "a compulsive reaction" to the boy's screams and struggle, a reaction that the defendant, due to his mental condition, "had no power to control."82 Although the court reaffirmed the settled doctrine that irresistible impulse does not constitute a de-

79. 64 Cal. 2d 310, 411 P.2d 911, 49 Cal. Rptr. 814 (1966). Conley involved the killing of a man and his wife by the wife's drunken and enraged lover, whom she had spurned in favor of reconciliation with ler lusband.

80. Id. at 322, $411 \mathrm{P} .2 \mathrm{~d}$ at $918,49 \mathrm{Cal}$. Rptr. at 822 . This statement is potentially problematic in two ways. First, by equating knowledge of the duty to conform to the law with the ability to harbor malice the court seems to have established a new category of manslaugher. Yet, if the free choice of an action is the measure of culpability, then knowledge of the law may bear upon the degree to which one could freely choose the action at issue. Furthermore, this standard conforms to the common law notion that ignorance or mistake of fact or law is a defense when it negatives the existence of a inental state essential to the crime charged (except that if the defendant would be guilty of another crime had the situation been as he believed, then lie may be convicted of the offense of which he would be guilty had the situation been as he believed it to be). LA Fave \& ScotT at 356; see CaL. PEN. CODE $\$ 26$ (West 1975). This is not to say that where a defendant merely believes his conduct was not proscribed by the criminal law he will be completely relieved of culpability; but where it can be shown that a mental disability has impaired knowledge of the duty to conform to the law that evidence should be admissible to reduce the seriousness of the crime.

Secondly, the language in Conley may have suggested that the Wells-Gorshen rule was to be limited to evidence of diminished capacity caused by one of the three "causes" listed by the court. Fortunately, interpretations of the decision have been broader. The California criminal jury instructions, for example, state that diminished capacity may be a "substantially reduced mental capacity, whether caused by mental illness, mental defect, or any other cause." CALJic $\$ 8.77$ (1974 Supp.). This is desirable, because if psychiatric evidence is to be introduced on the question of the defendant's ability to compreliend the law or to abide by the law, there is no reason to limit the evidence to three causal factors if other causes might similarly affect the ability to harbor malice aforethought.

81. 8 Cal. 3d 672, 504 P.2d 1256, 105 Cal. Rptr. 792 (1973).

82. Id at 679,504 P.2d at 1260,105 Cal. Rptr. at 796. Two of the psychiatrists who testified diagnosed the defendant as having a schizoid personality. Portions of their psychiatric evaluations are set out in greater detail in the opinion. Id. at $687 \mathrm{n.3}, 504$ P.2d at 1265-64 n.3, 105 Cal. Rptr. at 801-02 n.3. 
fense of legal insanity ${ }^{83}$ it held that "irresistible impulse due to mental disease is relavant on the issues of intent to kill and malice aforethought." 84

By centering upon the cognitive aspect, and recognizing the volitional characteristic of malice aforethought, the court has effectively identified the nature of that concept as one rooted in the individual's ability to choose freely to do a person-endangering act. Further support for this notion is seen in statutory second degree murder cases involving so-called "implied" malice, defined by the statute as evidenced by an "abandoned and malignant heart." that state of mind in which a defendant "for a base, antisocial purpose, does an act which involves a high degree of probability that it will result in death," 86 with wanton disregard for human life. ${ }^{87}$ When a jury determines whether a defendant had an "abandoned and malignant heart" in accordance with the stated definition, in reality it determines whether he had malice aforethought. ${ }^{88}$ Thus, that malice which is ostensibly "implied" must in fact be proven.

\section{IV}

\section{Psychiatry and the Law: Recognizing the Proper Roles}

In defining malice aforethought in terms of free will and declaring it a specific imtent capable of negation by evidence of diminished capacity, the Califorma Supreme Court has necessitated a frank reevaluation of the relationship between law and psychiatry. The law and the psychiatrist are each concerned with the same question: what factors mduced or compelled an individual to commit certain actions? At some point, however, the purposes underlying the inquiry-and the orientation of the inquirer-diverge. Whether or not psychiatrists would agree, the law, entrusted with the enforcement of society's collective moral judgments, draws distinctions between actions compelled by reasons such as coercion or self-preservation and those resulting from reasons

83. Id. at 685,504 P.2d at 1264,105 Cal. Rptr. at 800 .

84. Id. at 686, 504 P.2d at 1265, $105 \mathrm{Cal}$. Rptr. at 801. Under Conley and its progeny the error in not instructing upon irresistible impulse would have required reversal of the first degree murder conviction. In Cantrell, however, the court found no miscarriage of justice and affirmed the conviction because the record fully supported the conviction on a felony murder theory. Id. at 686-88, 504 P.2d at 1265-67, 105 Cal. Rptr. at 801-03.

85. Cal. Pen. CoDe $\& 188$ (West 1970).

86. People v. 'Thomas, 41 Cal. 2d 470, 480, 261 P.2d 1, 7 (1953) (Traynor, J., concurring).

87. Id.; People v. Washington, 62 Cal. 2d 777, 402 P.2d 130, 44 Cal. Rptr. 442 (1965).

88. See People v. Poddar, 10 Cal. 3d 750, 518 P.2d 342, 111 Cal. Rptr. 910 (1974). 
such as greed or malice. In one area, however, these legal distinctions are most difficult to draft: it is precisely in this area-concerning the exculpatory effects of mental incapacity less than legal insanity-that the psychiatrist's knowledge is most needed, and yet most threatening.

Underlymg the perceived threat of the psychiatrist to the worldview of the legal system is the classical free will-determinism dialogue. The outlines of the problem were set forth in an article by an eminent psychiatrist, Dr. Bernard Dianiond, which was quoted in Gorshen:

"Each act of will . . . turns out to be as rigidly determined as any other physiological process of the human body. Yet all of us continue to live our hives, make our clioices, exercise our free will, and obey or disobey the law as if we actually had something to say about what we are doing. Criminal law could not exist were it not for this posit that each normal person intends to do the act which he does do and that such intention is based upon the exercise of free will."ss

Read uncritically, this statement does pose a threat to the underpinnings of the criminal justice system, particularly if the requirement of unity of act and intent is applied strictly. The answer to this dilemma, however, rests in the words "posit" and "normal person." The law assumes, as it must, that there is a range of conduct within which normal individuals are able to exercise a degree of free cloice. Furthermore, by recognizing defenses based upon insanity, ${ }^{90}$ unconsciousness, ${ }^{91}$ and lunacy or idio$\mathrm{cy}^{92}$ the law acknowledges a range of activity which falls outside its basic assuntptions. Dr. Diamond's article clearly expresses this analysis:

"It does no good to proclaim to the jurist that scientific evidence proves that there is no such thing as free will. There is a subjective phenomenon which the normal individual experiences as free will. Illusory or not, free will remains the basis of all criminal law simply because free will is the basis of all normal social behavior."

"The task then becomes to understand the motivations, intent, and actions of the individual who deviates from the common-sense posit of free will."93

Whatever the abstract validity of this differentiation, the law has adopted it because-because it has to. In this regard the law and the psychiatrist are not at odds. In elaborating upon his position in testimony before

89. 51 Cal. 2d 716, 724 n.4., 336 P.2d 492, 497 n.4 (1959) (quoting Diamond, With Malice Aforethought, 2 ARchines of Criminal Psychodynamics 1, 27 (1957) [hereinafter referred to as Diamond] (emphasis added).

90. CAL. PEN. CODE $\$ 26$ (West 1970).

91. Id.

92. Id.

93. 51 Cal. $2 \mathrm{~d}$ at $724 \mathrm{n} .4,336 \mathrm{P} .2 \mathrm{~d}$ at $497 \mathrm{n.4}$ (quoting Diamond at 27-28) (emphasis added by the court). 
the trial court in Gorshen, Dr. Diamond expressed the sentiments of both professions:

"A posit is a working assumption. When I treat a patient, if I believed as a working assumption, that everything is predetermined or determined by forces outside of the patient's cloice and consciousness, there would be no point in my doing psycliotherapy or psychoanalysis, because obviously nobody would ever get better."94

Similarly, there would be no point in enforcing an organized system of morality without belief in the same assumption. The difficult question lies in defining where varying degrees of diminished mental capacity fall on the spectrum between that conduct which is "controllable," and therefore legally accountable, and that which is not. In answering this question equitably, the assistance of psychiatrists is of particular value.

Psychiatry's abstract "threat" to the law disappears as long as the respective funtions of the two professions are kept clearly in mind. The law sets the parameters within which psychiatric explanations are given meaning. Thus, for example, the law has defined malice aforethought as requiring a certain quantum of cognitive and volitional ability. A psychiatrist who testifies regarding a given defendant's mental capacity is not making a judgment about the individual's moral culpability, but rather offering an expert opinon as to the presence or absence of the legally-defined determinants of guilt and social blameworthiness.

Nevertheless, the respective roles of the psychiatric and legal professions do overlap. The legal doctrine which limits the degree to which voluntary intoxication may serve as a defense to crime, though relying upon certain factual assumptions about the effect of alcohol on volition, ${ }^{95}$ rests primarily and unmistakably upon social policy considerations. Accordingly, it falls squarely within the province of the law, not psychiatry. Where factual assumptions, rather than policy, form the underlying rationale of a legal doctrine, however, the psychiatrist's role should be expanded. Certain forms of mental disease or incapacity may be factually more akin to those legal considerations which lead to recognition of unconsciousness or lunacy as complete defenses to crime ${ }^{96}$ (regardless of general or specific intent) than to the legal considerations which lead to recognition of "heat of passion" as a defense only to a specific imtent crime. ${ }^{97}$ The law, ultimately, must decide if these factual assertions are correct and whether they should be applied.

94. 51 Cal. 2d at 724-25, 336 P.2d at 497 (quoting testimony in the trial court).

95. See text accompanying notes $47-48$ supra.

96. Cal. Pen. Code $\& 26$ (West 1970).

97. Heat of passion is a defense to the crime of murder which reduces the crime to manslaughter. CAL. PEN. CODE $\$ 192$ (West 1970). 
Nonetheless, in the discharge of its conceded duty to fashion society's tenets of moral culpability, the law has a continuing responsibility to rethink and reformulate its doctrines in the hight of new knowledge.

\section{V \\ Rethinking the Specific-General INTENT Doctrine}

In cases of malice aforethought and in situations such as Rocha's treatment of assault, the California Supreme Court has at times fallen back upon the specific-general intent dichotomy and substituted labels for analysis. Thus, extreme mental disorders have been held as defenses solely to the specific intent elements of a crime; defendants lacking capacity to harbor any criminal intent within the ineaning of Penal Code section 20 have, nonetheless, been convicted. This rigid limitation of the diminished capacity defense has excluded psychiatric evidence in an area in which it may be especially relevant and useful. Such a rule promotes no apparent social policy. Indeed, analysis of the rationale which properly underhes the relevant cases and doctrines provides the foundation for a critical reconsideration of this rule.

Such a reconsideration was urged upon the court in People $v$. Noah. ${ }^{98}$ The defendants, Meyers and Noah, had been attacked with a knife by another inmate and had employed extrene force in rebuffing the attack, inflicting 40 to $50 \mathrm{stab}$ wounds on their assailant. Their defense to the charge of aggravated assault was that they had acted in self-defense and that their excessive force resulted from an uncontrollable rage caused by inental defect or disease. Evidence was offered indicating that Noah had an "abnormal electroencephalogram indicating brain malfunction which would affect his ability to exercise rational judgment in high stress situations." ${ }^{\text {"99 }}$ A psychiatrist testified that Noah's judgment and control were so impaired that he was probably unable to distinguish right froin wrong during the fray and that he probably did not realize that his attacker had broken off the attack. ${ }^{100}$ The defendants

98. 5 Cal. 3d 469, 487 P.2d 1009, 96 Cal. Rptr. 441 (1971). In this case the defendants, one serving a life term and the other serving a term for less than life, were convicted under Penal Code section 4501 relating to assaults by prisoners. The California Supreme Court affirmed the conviction of the defendant serving less than a life term, but held that since the relevant Penal Code section apphed only to those serving less than life terms, the other defendant could not be convicted under that section. However, the court found that the jury had necessarily found all the elements of the crime of as. sault. The court therefore modified the judgment as to the defendant serving a life term to reflect conviction under section 245(a) of the Penal Code and affirmed the conviction as modified.

99. Id. at 474, 487 P.2d at 1012, 96 Cal. Rptr. at 444. Evidence was also introduced indicating that Meyers' capacity to form malice vas impaired.

100. Id. 
contended that the trial court did not adequately instruct on the effect of diminished capacity caused by mental disease or defect on the general intent to commit crime:

In essence defendants argue that since intent $\ldots$ is an element of every crime (Pen. Code $\S 20$ ), and intent presupposes at least a minimal ability to act volitionally, "irresistible impulse" due to mental disorder is a complete defense under a plea of not guilty. ${ }^{101}$

Concerned with the prospect of overruling the long-standing California rule that irresistible impulse is not a complete defense to crime, the court dismissed defendants' contention by relying upon Penal Code section 21: "The intent or intention [of section 20] is inanifested by the circumstances connected with the offense, and the sound mind and discretion of the accused. All persons are of a sound mind who are neither idiots nor lunatics, nor affected with insanity." ${ }^{02}$ The court stated:

Defendants' novel theory founders on the shoals of Penal Code section $21 \ldots$. Section 21 makes clear that an otherwise competent defendant who is not insane, a "lunatic," or an "idiot," is capable of achieving that general intent required by section $20 \ldots$ Although the mental conditions of lunacy and idiocy are not necessarily the same as legal insanity ... that mental abnormality manifesting itself in conduct which defendants describe as the product of "irresistible impulse" las never been judicially recognized as either "idiocy" or "Iunacy." To the contrary, irresistible impulse has been consistently rejected as a complete defense to crime in this state. ${ }^{103}$

Unfortunately, the court's "novel theory" of the illumination shed by section 21 founders on the shoals of its previous analysis of the statute. In Gorshen, the court had unequivocally stated "[s]ection 21 is of little aid in appraising either general or specific intent." 104 There the court had pointed out that although one inay objectively inanifest discretion or a sound mind, he inay still lack criminal intent because, for example, of unconsciousness. ${ }^{105}$ Similarly, the second sentence of section 21 , which Noah had enphasized, was considered by the Gorshen court to be "not very enlightening. In this state there appears to be no statutory or judicial definition or test of idiocy or lunacy as related to [sound inind]." 100 Noah's examination of the concept of "sound mind" is

101. Id. at 477,487 P.2d at 1014,96 Cal. Rptr. at 446 .

102. Id. at 478,487 P.2d at 1014-15, 96 Cal. Rptr. at $446-47$ (emphasis added by the court).

103. Id. at 477-78, 487 P.2d at 1014-15, 96 Cal. Rptr. at 446-47 (emphasis added).

104. $51 \mathrm{Cal}$. $2 \mathrm{~d}$ at $728,336 \mathrm{P} .2 \mathrm{~d}$ at 500 . In the 12 years intervening since Gorshen there had been no California Supreme Court decisions questioning Gorshen's view of section 21 or expanding upon its meaning as it relates to the issue at hand.

105. Id. at 728-29, 336 P.2d at 500 .

106. Id. at 729,336 P.2d at 500 . 
totally unsatisfactory ${ }^{107}$ No attempt was made to define what the statutory words "lunatic" or "idiot" mean or should mean; instead, the court simply suggested that whatever the words mean, they have never before been judicially recognized to encompass "irresistible impulse."108

More disingenuous than Noah's handling of "sound mind" is its non-handling of the concept of "discretion." Sound mind and discretion are equally relevant in the statutory definition of criminal intent. Furthermore, a defense based upon volitional incapacity would, by definition, more properly be considered directed to the discretion element of the statute. Nonetheless, the court was totally silent on this specific issue, limiting its discussion, instead, to sound mind and to the general rejection by past decisions of a total defense based upon irresistible impulse.

Noah quoted Gorshen as authority for the proposition that evidence of irresistible impulse is a partial rather than a complete defense, negating specific but not general intent: ${ }^{100}$ Gorshen's discussion of irresistible impulse, however, is notable more for its specificity than its breadth; the court's reinarks were generally addressed to the fact that irresistible impulse has been "rejected in this state as a test of the defense of legal insanity." ${ }^{110}$ Nowhere in Gorshen did the court explicitly discuss whether irresistible impulse might be a coinplete defense on a theorysuch as was raised in Noah-other than legal insanity. ${ }^{111}$

107. For reasons set forth by Justice Traynor, lunacy and idiocy are not synonymous with legal insanity. People v. Baker, 42 Cal. 2d 550, 568-69, 571, 268 P.2d 705, 716-18 (1954). Gorshen reaffirmed this proposition. $51 \mathrm{Cal} .2 \mathrm{~d}$ at 729, $336 \mathrm{P} .2 \mathrm{~d}$ at 500 . Noah, however, equivocally states that lunacy and idiocy "are not necessarily the same as legal insanity." 5 Cal. 3d at 478, 487 P.2d at 1015, 96 Cal. Rptr. at 447 (emphasis added).

108. 5 Cal. 3d at 478, 487 P.2d at 1015, 96 Cal. Rptr. at 447.

109. Id.

110. $51 \mathrm{Cal} .2 \mathrm{~d}$ at 726, $336 \mathrm{P} .2 \mathrm{~d}$ at 498. Elsewhere the court makes clear that the broad language rejecting irresistible impulse in a previous case, "must be considered in its context; it was made in the course of an opinion which holds that irresistible impulse does not constitute the insanity which is a complete defense . . ." Id. at 727, $336 \mathrm{P} .2 \mathrm{~d}$ at 499 (emphasis added).

Similarly, the broader language from Gorshen, quoted in Noah, must be read in its context. It was preceded by a specific discussion noting that irresistible impulse is not recognized as part of the defense of legal insanity, and presumably, the broad language was intended to be limited by the previous discussion.

111. This is not meant to imply that Gorshen's specific language was necessarily intended to open the door to such a theory; but rather that its language, despite Noali's assertion to the contrary, does not close the door. However, it should be noted that the court's discussion of the kind of expert testimony to be admitted indicates that the court is not entirely neutral on the issue:

Such expert evidence, like evidence of unconsciousness resulting from voluntary intoxication, is received not as a "complete defense" negating capacity to commit any crime but as a "partial defense" negating specific mental state essential to a particular crime.

Id. at 727,336 P.2d at 499 . 
Given the court's well-known hostility to the concept of "irresistible impulse," the defendants in Noah would have been well-advised to phrase their appeal in other language. This, however, does not justify the court's refusal to address itself to the meaning of "discretion." That term is an explicit element of the very Penal Code section which the court employed to quelch defendants' contentions. Besides the immediate injustice done to the defendants, the court's inexplicable omission constituted a far greater disservice. Whatever the legislative intent may have been in employing the word "discretion," that intent was thwarted by the court's failure to define and apply the term once the issue was before it.

If indeed past precedent bars the use of irresistible impulse as a complete defense, this doctrine should be read narrowly. Other forms of involuntary diminished capacity, not stigmatized by the irresistible impulse label, should constitute complete defenses if they sufficiently impair volitional abilities. ${ }^{112}$

Even if Noah is narrowly read to carve out a special exception for irresistible impulse, the opinion presents an unflattering portrait of justice fettered rather than guided by past decisions. Other than a possible fear that claims of irresistible impulse are not easily susceptible to proof or disproof, the court had no reason to deny the defense in relation to general intent crimes. Particularly in areas where new scientific learning may render previous legal doctrines obsolete, the court has an affirmative obligation to rethink its previous formulations. In Noah the court failed to meet this obligation both in its holding on irresistible impulse and its general silence upon the increasingly inadequate specific-general intent dichotomy.

Unlike Noah, Hood and Rocha rest on firmer and more understandable policy grounds. Although both Penal Code section 22 and Rocha hold that voluntary intoxication is not a defense to a general intent crime, Rocha also mdicates that a defense of diminished capacity caused by a defect other than intoxication need not necessarily be limited to specific intent crimes. The court stated:

112. Other states have recognized irresistible impulse as a complete defense. E.g., Parsons v. State, 81 Ala. 577, 2 So. 854 (1886); Downs v. State, 231 Ark. 466, 330 S.W.2d 281 (1959); Flowers v. State, 236 Ind. 151, 139 N.E.2d 185 (1956); People v. Sharac, 209 Mich. 249, 176 N.W. 431 (1920); State v. White, 58 N.M. 324, 270 P.2d 727 (1954), aff'd on rehearing, 61 N.M. 109, 295 P.2d 1019 (1956); State v. Kirkham, 7 Utah 2d 108, 319 P.2d 859 (1958); Thompson v. Commonwealth, 193 Va. 704, 70 S.E. 2d 284 (1952); State v. Riggle, 76 Wyo. 1, 298 P.2d 349 (1956), cert. denied, 352 U.S. 981 (1957).

The historical reason given for California's rejection of the irresistible impulse test is that it is difficult to prove or disprove and that it is inconsistent with the deterrent purposes of the criminal law. People v. Hubert, 119 Cal. 216, 223, 51 P. 329, 331 (1897). 
In People v. Hood . . . the issue of whether simple assault and assault with a deadly weapon are general or specific intent offenses was reexamined. Faced with the assertion that voluntary intoxication should be a defense to those crimes, we declined to categorize the intent requirement as either general or specific, but ruled that thc "nature of the requisite intent is such that it is not susceptible to negation though a showing of voluntary intoxication."113

The specificity of this statement indicates that the court's holding was concerned with cases of voluntary intoxication. The only meaningful rationale offered to support the rule was the clear public policy argument. Support for this proposition was evidenced in People v. Conley:

The union or joint operation of act and intent or criminal negligence must exist in every crime, including manslaughter . . . and is deemed to exist irrespective of unconsciousness arising from voluntary intoxication. An instruction that does not distinguish unconsciousness caused by voluntary intoxication from that induced by other causes is erroneous. ${ }^{114}$

Thus, deinonstrable inental incapacity, other than voluntary intoxication, that significantly affects the actor's ability to choose and to act in accordance with his choices should constitute a complete defense. If "discretion" Ineans anything, it should mean this inuch.

Two approaches to this end may be considered. ${ }^{115}$ One is to eliminate the inflexible specific-general intent dichotony entirely and focus instead upon more carefully defined requisite mental states; the second would retain the specific-general intent doctrine, but allow the introduction of evidence of dimimished capacity, other than voluntary intoxication, relevant to general intent. The first approach is preferable because it preserves the original purpose of the specific-general intent doctrine, while discarding the labels that have been the cause of so much judicial confusion and abuse, and that have at times been either too inflexible or too vague. Furthermore, under this approach, the social policy mandating exceptions to the general rule could be acknowledged frankly, with less constraint due to previous judicial formulations than would otherwise exist.

113. 3 Cal. 3d at 897, 479 P.2d at 375, 92 Cal. Rptr. at 175 .

114. $64 \mathrm{Cal} .2 \mathrm{~d}$ at 324,411 P.2d at 919-20, 49 Cal. Rptr. at 823-24 (emphasis added).

115. A third alternative, not discussed here, is embodied in the English Homicide Act of 1957, which does away with "constructive malice" and provides a broad definition of diminished responsibility: one is not convicted of murder "if he was suffering from such abnormality of mind (whether arising from a condition of arrested or retarded development of mind or any inherent cause or induced by disease or injury) as substantially impaired his mental responsibility for his acts and omissions in doing or being a party to the killing." Homicide Act of $1957,5 \& 6$ Eliz. 2, c. $11, \S \S 1,2$. One who would otherwise be liable as principal or accessory to murder is, instead, liable for manslaughter. $I d$. $\$ 3$. 
If for some reason the California Supreme Court is loathe to abandon the specific-general intent dichotomy, however, the second alternative-allowing the introduction of evidence of diminished capacity relevant to general intent-should be adopted. This approach, too, would ensure proper consideration of both act and intent by providing courts with the flexibility to define the requisite mental states for each crime more narrowly. It would allow courts and legislatures the leeway to foreclose certain defenses-such as voluntary intoxication-for reasons of public policy, while encouraging a more enlightened analysis of other defenses-such as lack of volition or discretion-as new evidence supporting them was developed.

Pragmatically viewed, this second approach is more likely to receive judicial attention because it retains the specific-general intent dichotomy; if a specific intent is negated, the defendant nnay still be found guilty of a lesser included general intent crime. This provides a societal "safety valve" that would be destroyed if the specific-general intent doctrine were eliminated. In cases where acquittal might cause the release of a dangerous individual, however, a partial answer to this concern would be a judicial determination of the defendant's dangerousness in a civil proceeding after acquittal. ${ }^{116}$ If the second approach were chosen, however, the definition of "general intent" would need to be carefully considered, since an overly broad definition might, by giving the diminished capacity defense the effect of an automatic complete defense, force diminished capacity into the area covered by the insanity defense, thereby contributing to the eventual demise of the defense itself. However, the problein should be susceptible to judicial treatment. Where one is aware of wrongdomg and is capable of controlling his actions, then he should be deemed to possess the general intent required for crime. Evidence of disorder or defect-even senility, for examplewhich could inipair this intent would be heard and evaluated by the jury. Thus, even reckless activity could be included in the defimition of general intent, but negligent activity might be excused if the nature of the diminished capacity were sufficient to account for the negligence.

Under either approach, the prospect of admitting psychiatric evidence may be of concern to those who do not have confidence in the reliability of psychiatric testimony. Nonetheless, besides the considerations inentioned above, ${ }^{117}$ it should be remembered that in inost cases both prosecution and defense will use psychiatric evidence and that the

116. A psychotic who thought God told him to assault someone might lack general intent, but he might pass the M'Naughton "right and wrong" test. A civil commitment, based upon the court's determination that the defendant was somehow "dangerous," could be rehed upon at this point.

117. . See section III supra. 
jury-which embodies the changing values of society-will be asked to choose between the evidence presented. ${ }^{118}$ This jury function would be entirely in accordance with other determinations made by the jury, such as when it decides whether or not to behieve an eyewitness or which of two opposing ballistics experts to believe. ${ }^{119}$ The jury would function as an assurance for society that psychiatric evidence is not being allowed to pervert justice unfairly in favor of the defendant, and the defense would be required to show that Dr. Diamond's "working posit"120 has been overturned in a specific instance.

Both approaches focus greater attention upon the full implications of the concept of the unity of wrongful act and intent. Statutory terms currently in force which would further this effort should no longer be allowed to languish, nor should doctrines persist if they inhibit rather than encourage a creative response to this problem. These approaches, involving termination or radical modification of the specific-general intent dichotomy, would better serve the social policy considerations the doctrine was evolved to promote.

118. Defense and prosecution psychiatrists may agree as to the mental state affecting a defendant, but they may disagree as to how the mental state affected the crime itself. Thus, even where the existence or nature of the defect was not an issue, the question of causality would be answered by the jury.

In order to ensure that the jury has the opportunity to exercise its judgment, the defense should be required to affirmatively plead or indicate that a dininished capacity defense will be raised. Although the experienced prosecutor will probably know when a diminished defense is likely, the current law - which does not require early defense disclosure of a contenuplated diminished capacity defense - makes it possible that a prosecutor who does not expect the defense will not be prepared to cross-examine the defense psychiatrist or, even worse, will fail to present rebuttal psychiatric testimony.

This raises some issues not considered in this Comment. Should there be courtappointed psycliatrists for diminished capacity cases; and should the prosecution psychiatrists be allowed to interview the defendant notwithstanding objection by the defense? Constitutional problems - most notably the issue of self-incrimination - impinge upon these questions.

119. The fact that psychiatric testimony is not always reliable should not alone affect its admissibility. Even eyewitness testimony has been shown to be unreliable. See, e.g., Buckhout, Eyewitness Testimony, ScIENTIFIc AM., Dec. 1974, at 23.

120. See text accompanying notes 93-94 supra. 